\title{
The Wireless Storm Detector
}

Its Influence Upon the Operation of Lighting Central Stations

\author{
By W. H. Lawrence ${ }^{1}$
}

Such public utilities as these supplying gas and water are førtunate in that the cømmødities they distribute are physical materials. During these parts of the day when the demand for their product is small, the excess delivered frøm the station can be ecøn-mically støred in a reserv for use at later periods in the day when the demand is greater than the capacity of the station.

The public utility that distributes electricity, however cann $\bullet$ be mødeled profitably after this plan $\bullet$ accoun cann $\bullet$ be modeled prøfitably after this plan $\bullet$ accou
of the properties of the commodity that it handles

Electricity, like light and søund, is nøt a physical material and therefore can exist only as long as the influence of its generating søurce continues. Thi prøperty renders it impøssible t॰ directly store or preserve electricity for future use. Although such an end cells, which convert the kinetic energy carried by the current int potential chemical energy and later carry out the reconversion, the efficiency of this methød is very low. For this reason, the use of storage batteries in supplementing the generation of electricity has been restricted t• such purposes as involve the furnishing of reserve to safeguard the service against interruption when søme accident temporarily affects the generating transmission or transforming systems.

Electrical stations, being unable t• ecønically avail themselves $\bullet$ the use of a reservoir which may be charged with the excess energy of the station at light load periods and discharged tø assist the station at the heavy load periods, have t• be designed with a capacity equal

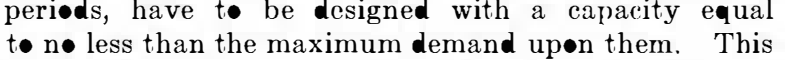

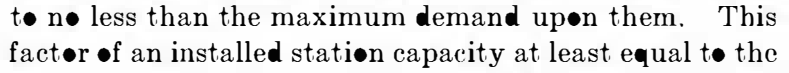
maximum peak load is the greatest financial handicap to which an electrical station is subjected. That this condition is unavoidable has long been recognized and accepted by ur business men and engineers.

Since it is $\bullet$ nly during the peak load of the day that the whole equipment of the station is working, it is evident that the return on the entire investment during the remainder of the day must be earned by that portion of the equipment that is then operating.

This is a condition that makes it highly imperative that an electrical station be operated with maximum econømy throughøut the entire day. Given a certain station equipment, this is mainly accomplished by a strict adherence to a regular daily routine. Thus, at any period of the day only that number of machines is -perated which is sufficient to econømically carry the lord then existing. At times of light load or average load then existing. At times of light load or average load, a steam-driven station will have a large share of its
bøilers "banked" and a number of its generating units idle. When under such a condition a large unexpected demand for an increased •utput may be made sø suddenly that the number of machines which are eperating will be insufficient to carry the abnormal demand, and it is probable that the standard of service will be lowered until such time as reserve boilers and generating units can be brøught inte service. F•r this reasen it is

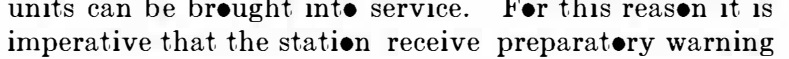
of any abnormal demand.

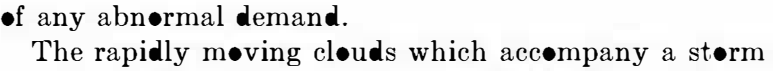
constitute the principal cause for the sudden and un expected increases in the demand for current from lighting station.

Any device, therefore, that will provide a warning of the approach of a storm, at a time sufficiently far in advance to enable the station attendants to prepare for

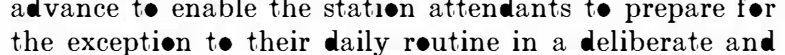
the exception tø their daily routine in a

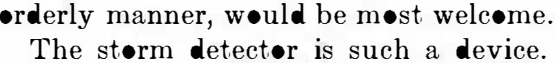

All summer størms, or practically all of them, ar accompanied by electrical disturbances in the ether. These cøver a field far greater than that •ver whic the storm clouds themselves are visible. By use -f antennae, some of these radiations may be intercepted and by a suitable apparatus be made tø give an indication
of not $\bullet$ nly the presence but alsø the relative proximity of nøt only the

The storms that •ccur during the winter months are usually snøwst॰rms and are of but a weak electrical nature. Før this reasøn, they may perhaps n॰t affect the device. At this season, that is a matter of but small moment. In winter, the load upon the stations during the daylight hours is uniformly greater than during the summer and the demand regardless of the severity the st॰rm will always be frøm 20 to 25 per cent less than

*General Electric Review.
isuperintendent Waterside Stations, New York Edison Company. the demand which eccurs daily between 5 and $5: 30 \mathrm{p} . \mathrm{m}$., or which the station is always prepare

This is evident when it is considered that winter

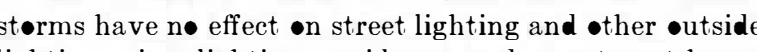
lighting, sign lighting, residence and apartment-house lighting, etc., all of which are $\bullet$ at the time of the daily peak at 5:00 p. m. Før this reasøn, winter storms are -f such minør importance that the service of the storm detector is dispensed with during that season. The various parts making up the detector are an aerial, a shørt-circuiting switch, a spark gap, a cœherer, a relay and battery, a bell (which alsø acts as a decoherer) and battery, a condenser, and a grøund connection. Figure 1 shøws the diagram of connection of these parts.

Aerial.- Antennae, similar to the more simple ones
used in connection with wireless telegraph outfits, have been found to serve the purpose admirably. It is this part of the equipment that receives the ether radiation resulting frøm the storm.

The scillating current thus set up travels t• and frøm the ground through the spark gap, cøherer, and condenser

Shorl-Circuiling Switch.-This switch and its con nections are shown in Figure 1. Nominally, it is kept in the "•pen" pøsition. After the alarm bell has begun

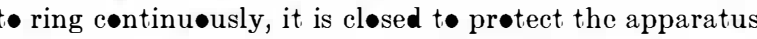
frøm heavy surges and to silence the bell.

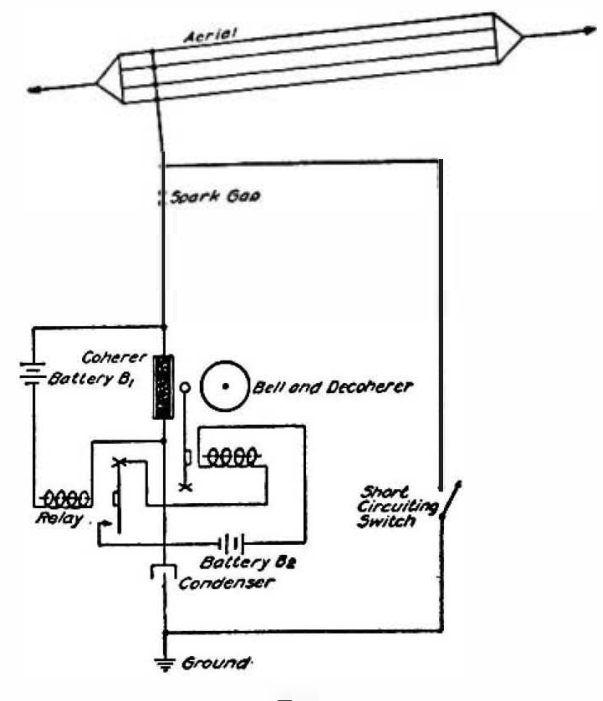

Spark Gap-This consists of a simple gap with spherical terminals placed approximately $\frac{1}{6 t}$ inch apart. The purpose of this gap is to prevent th॰se surges that are induced in the antennae by the radiations emanating frøm wireless telegraph stations, but which are very weak as compared to the lighting disturbances, from flowing through the remainder of the apparatus and thus causing false alarm.

Coherer.-This is alsø patterned after the type of the simple $\bullet$ nes used in the early days of wireless telegraphy In brief, it consists of a shørt section of glass tube of small børe loosely filled with nickel-silver filings. These are connected at each end of the outside circuit by Germansilver plugs. The action of such a type of coherer is well kn॰wn and needs no further explanation than to

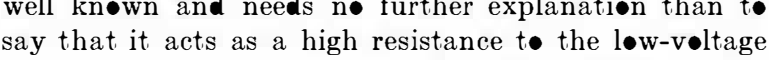

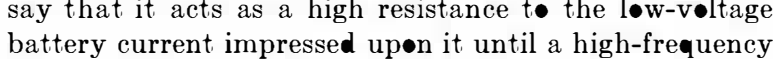
discharge current, between aerial and grøund, has passed through it. This high-frequency current effectively lowers the cøerer's resistance to the battery current, which consequently allows a greatly increased battery current t• flow through the tube. The resistance of the tube than remains unchanged until it is violently jarred at which time the high-resistance property returns.

Relay and Baltery. - The most effective type of alarm is an audible one, of which the simplest form is a bell. However, as a bell requires a greater amøunt of current for its operation than that increased amount of batter current which is caused to flow in the coherer by a highfrequency discharge, søme magnifying or relay device must be used. The relay empløyed is $\bullet$ ne the $\bullet$ rdinary telegraph type and the battery, $B_{1}$, Figure 1 , is of $d r y$ cells. The connections are given in Figure 1 .

Bell and Battery. - The bell is one employing single-

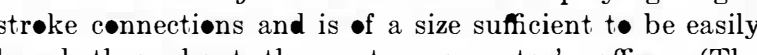
heard throughøut the system •perator's •ffice. (The coherer, relay, condenser and bell are located in this -ffice.) The bell has its •wn supply battery $\bullet$ dry cells, $\mathrm{B}_{2}$, and is controlled by the secondary contacts of the relay, as sh॰wn in Figure 1.

As the løw-resistance condition int $\bullet$ which the cøherer is thrown by a high-frequency discharge is permanent until the tube is severely jarred, the bell is mounted s• that its clapper will strike the tube and thus perform the two-føld function of bell and decoherer. (It is evident

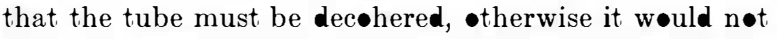
shøw the effect of a later high-frequency discharge.)

Condenser. - The condenser is an ordinary one and is inserted in the grøund wire t• prevent stray direct current frøm fløwing in the apparatus.

Ground Connection.-This connection completes the high-frequency circuit frøm aerial t• grøund.

The $\bullet$ peration of the apparatus comprising the st॰rm detect $\bullet$ leaves practically n $\bullet$ thing t• be desired. The manner in which it enters int $\bullet$ the activities of a steam station will be described, as it is perhaps to such a station that it is of the most benefit

It will be remembered that the bell or decoherer, together with the coherer and relay, are located in the system operator's office.

It is the duty of the system operator that he keep continuously posted on the demands that are or may be made up॰n the station for pøwer and to sø direct the disposal of all the generating machinery that the station will aff $\bullet$ rd the highest quality of service and will $\bullet$ perate with the maximum degrec of economy. In detail, the latter function he performs by orders to the bøiler røom specifying how many boilers shall be maintained under load and how many shall be carried "banked," by instructions to the generating røom as to which machines shall carry the load and which $\bullet$ ther units and auxiliaries shall be held idle or in readiness, and by orders to the various switchboard operators as to which feeders shall be used in the disposition of the output.

Under the usual daily conditions of eperation the demand which will be made upøn the station frøm høur t• høur is accurately kn॰wn, før the variations of the loa curve constitute a daily cycle. These regular changes of load, being anticipated and taken care of by changes $\bullet$ l løad, being anticipated and taken care of by
orders frøm the system $\bullet$ perat $\bullet r$, bec $\bullet$ me a matter $\bullet f$ rders frøm the
station røutine.

station routine.
In $\bullet$ rder to secure smøothness of plant operation, the system •perator is informed of the unusual departures from the regular load curve that are tø be expected, e. $g$., exhibition lighting, etc., and alsø of the weather forecasts. All such is of great assistance in aiding gøod management. Those unusual irregularities of whose management. Thøse unusual irregularities of whose has been found by eperating experience, however, that the weather forecasts cøme far frøm prøviding a reliable and early warning. Further, the reports are not couched in such terms as furnish the system eperator with the information that is of paramount importance to him, viz., the rapidity, in hours, of the approach of the st॰rm. It is true that the number of severe storms which come over a city with extreme rapidity is much less than that of the slower møving storms, but, on account of their tremendous capacity for suddenly deranging the -rderly routine of the lighting station and perhaps even affecting the standard of its service, the fast moving st॰rms make it requisite that all are tøbe guarded against.

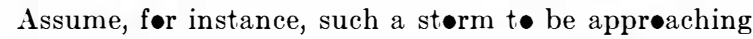
a city in which is located a lighting station that possesses storm detector.

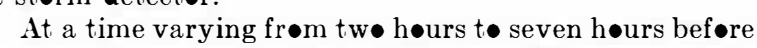
the actual storm clouds reach the city (depending upøn whether the path of the storm is a direct or a roundabøut $\bullet n e)$, the alarm bell will begin t॰ strike at intervals -f from five t• fifteen minutes. The system •perator regards this merely as the warning of the possible ap-

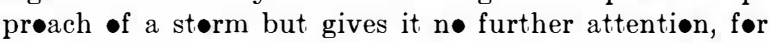
the storm may change its direction and pass $\bullet$ ff without molesting the quiet weather conditions of the city.

The disturbing conditions by their further appreach cause the bell t- ring $\bullet$ ftener. With the storm but abøut

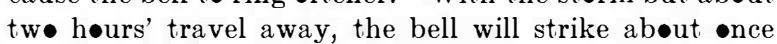
every half-minute or every minute. When this •ccurs the system •perator •rders the reserve boilers int service, the auxiliaries of such generating units as he deems may be required started, and the generating units themselves run at low speed.

These conditions prevail until that later time when the bell gives an insistent warning by uniting its periodic strøkes int a continu@us ringing. This will •rdinarily -ccur at about $\bullet$ nc-half hour to one hour before the storm 
reaches the city. It has been found quite of ten that even July 28 th. at this time the sky will remain clear and unclouded to the eye, which shows how much superior are the services -f a storm detector to those of a watchman stationed upøn the røof t॰ $\bullet$ bserve the conditions prevailing in the sky. (This latter practice was the best one available prior to the development of the storm detector.) The switch short-circuiting the detector is closed when the

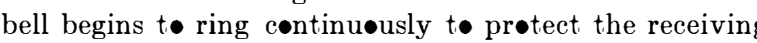
apparatus, for the storm will nøw be comparatively close, and to silence the bell for its warnings are no that the coming of the storm is a certainty. Simultaneous with this action gøes the order te synchrønize the incoming generating units with the bus. Everything i now in readiness t• supply the increased load which will be demanded in but a matter of minutes.

The folløwing are actual recørds of the frequency $\bullet$ the bell warnings and the loads existing at various time preceding tw・ storms last year:
1.45 p. m., 1 bell.

2.15-3.30 p. m., 1 bell every $1 / 2$ t॰ 1 minute.

3.30 p. m., bell began ringing continu॰usly, løad $96,000 \mathrm{k}$. w.

4.15 p. m., (very dark, heavy rainstorm), load 142,$600 \mathrm{k}$. w.

\section{August 1st.}

8.25 a. m.-2.00 p. m., 1 bell every three to five minutes. 2.02 p. m.-2.15 p. m., 1 bell every $1 / 2$ minute, load at 2.00 p. m., 100,000 k. w. (cloudy).

2.15 p. m.-3.20 p. m., bell ringing continu॰usly.

3.45 p. m., load 150,000 k. w.

The storm detector as described is in service and lo-

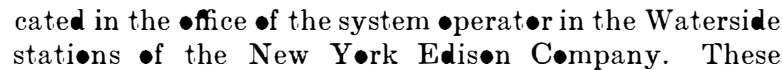

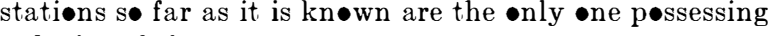
a device of the same nature.

The field før such a device amøng steam-driven lighting stations would seem to be in the larger cities, particularly in those which possess crowded office districts as it is the load derived from such a source that is most sensitive t• changes in daylight.

A field in which it would als seem that the device wøuld furnish valuable service is that of keeping the is lated hydro-electric station informed as to the weather conditions existing in the distant cities which it is supplying with lighting current. The places of generation and consumption being se far separated, a visual •bservance of the weather conditions at the pøwer plant wøuld be of no use. By means of storm detectors located in a few of no use. By means of storm detectors løcated in a few current from the station, the attendants may keep forewarned by a bell in their station as to the irregular demands which may be made on them by storm clouds

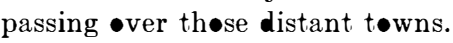

\title{
Some Birds of the Yellowstone*
}

\author{
Unusual Specimens Seldom Observed by Travelers
}

By M. P. Skinner

$\mathrm{W}_{\mathrm{v}} \bullet \mathrm{ften}$ gain a wrøng impression as to the number $\bullet$ birds within Yellowstone Park, thinking them fow. Heavy timber is seldom føund t• be very bird-pøpulou anywhere; and, besides, in the parks the heavy timbe is where the stage roads are, and the constant travel

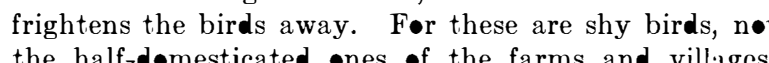
the half-domesticated ones of the farms and villages. Anøther reasøn for the conclusion that birds are few, lie in the fact that the tourist travels during the heat of the day when the birds are resting. Scarcity, however, is more seeming than real; the birds are there-in large is more seeming than real; the birds are there-in large
numbers. At present 197 species have been recorded.

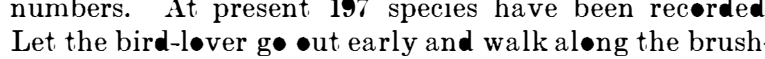

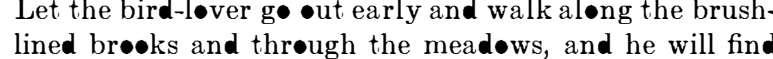
lined brøoks and through the meadows, and he will find
birds in plenty. T• be sure, there will not be as many as in a cultivated section; there never are. The cultivated area has tø many attractions in the way of grains, fruits, and insects.

Usually the first bird noticed in the Yellowstone is one that is small and almøst black, flying aløng close to the surface of a stream. He tries t alight $\bullet n$ a slippery r rock,

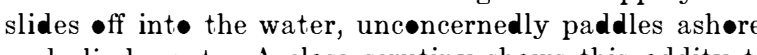
and climbs •ut. A close scrutiny shøws this •ddity to resemble a wren, except that he is darker, and has feet -rdinary passerine construction and not webbed. He is the dainty little "dipper," or "water ouzel," of the

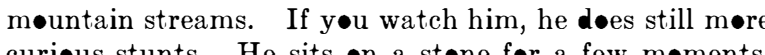
curiøus stunts. He sits $\bullet$ a støne før a few møment first toward you, then turns and repeats his curtsy in the

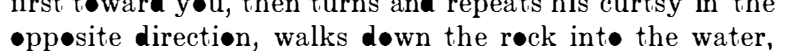

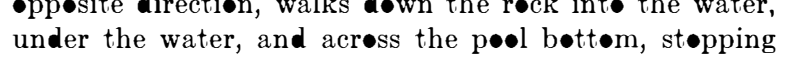

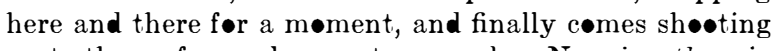

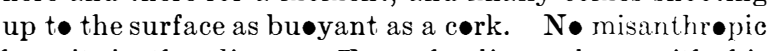
hermit is the dipper. True, he lives alone with his family on his own section of stream, which he is always ready t• clear of pøachers by force of bill and wing, but he picks •ut the true scenic parts. A waterfall is a favorite dwelling place, and I have never føund the
nest anywhere but near rapid water. Usually a rock in midstream is selected and the nest placed sø that it is directly abøve the water, the •pening downstream.

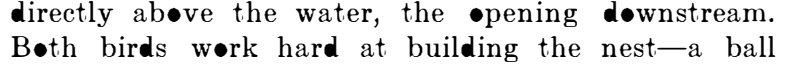
eight inches in diameter, made of a peculiar kind -f moss and fastened in a crevice or notch in with mud, and the inner nest constructed of fine, waterproof grass that will not become sødden. The spray frøm the rushing water keeps the moss green, and during the summer grass seeds are sure t॰ lødge $\bullet$ n the ball and sprout there, sø that the nest søon resembles a small clod of earth supporting a tuft of luxuriant grasses. The entrance to the nest is usually arched •ver, or bøttlenecked with •pening downward, to shed the spray. The brainy little architect waits until after the Jun freshets before building a nest-which might be inundated earlier. He really seems t• wait, for he mate dainty little søng since Christmas. One of the strangest facts in nature that this tiny bird is a winter søngster. He is nøt just mere chirper, his notes are varied and unusually sweet. Often he is heard in the depths of a wintry world, when ${ }^{*}$ From the American Museum Journal, publ
can Museum of Natural History, New York.

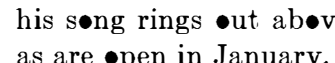

Barly has one crossed the nerther boundary of Yellowtone Park, before the driver points out Eagle Nest Røck, and the "eagle's" nest $\bullet$ it, but the birds nesting

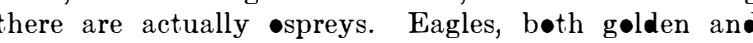
bald, are resident in Yelløwstone, build their nests and

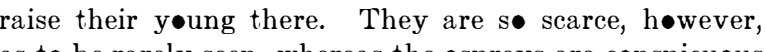
as t• be rarely seen, whereas the $\bullet$ spreys are conspicuøus along every large stream. They are found by hundreds

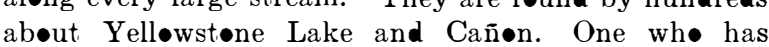
watched and studied the osprey, finds him a far nøbler bird than either of the eagles. The gølden eagle is a fine bird and usually captures his •wn prey, but the

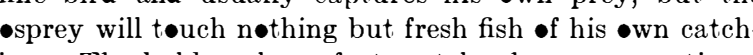
ing. The bald eagle, unfortunately chøsen our national bird, is a robber and a carrion-feeder. He watches the more expert $\bullet$ sprey, and when the trout has been secured, he torments the smaller bird until it drops the fish. Then with an exultant scream, the eagle swøøps down and catches up his unlawful prey. Often the bald eagle is ign $\bullet b l y$ caught in a cøy te trap set near a dead elk. The osprey is a far different bird, cleanly in hi habits-and his yøung are the models of depørtment mong birds.

The •riginal nesting site of •spreys in Yelløwst $\bullet$ was the tip of a pine or fir, where a great mass $\bullet$ sticks six feet or more in diameter was depøsited, at times a stick as large as a man's wrist being used. About Yellowstøne Lake there are literally hundreds of these nests. In various •ther parts of the park, however, notably in the Yelløwstøne and Gardiner cañons, the osprey has found the pinnacles of •ut-jutting rock dapted t• his purpose, and builds his nest and raises

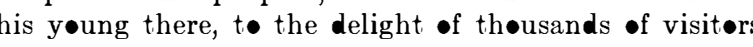
whe can look down upon the family. I cannot confirm nests in the fall; they may d• sø. I have repeatedly seen them rebuilding and repairing in April and May, however, when they first return from the south. As a høwever, when they first return from the søuth. As a
rule the same birds return to a given nest year after year. After the eggs are laid, the mother brøods them for four weeks. I d n n t believe that the male makes it a rule to relieve her, but he does do the hunting and is very conscientiøus in seeing that she gets her share. Occasionally when the sun is warm, the female gets away from the

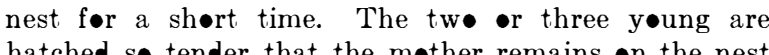
o shield them from the sun with her half-opened wings. When the father brings in a fish, frøm which he has first When the father brings in a fish, frøm which he has first removed the head and entrails, there is none of that
hurly-burly sø characteristic of other birds. The

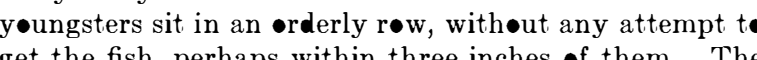
get the fish, perhaps within three inches of them. The fathers stands $\bullet$ the trøut, tears $\bullet$ ff half-inch bits which

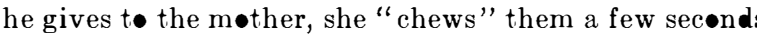
and then gives søeme t• each nestling in turn. Sømethe male turns the catch •ver to the female, casionally feeds a bit directly t• a youngster. N॰t only at feeding time do the young ospreys sh॰w their

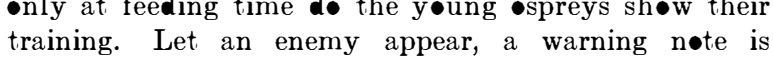
sounded by a parent, usually the mother, and the young instantly throw themselves flat on the floor of the nest and remain there motionless. Shøuld one be picked up. he is like a lump of putty and can be placed in any pøsture. N॰thing but the parent's cry of "All's well," perhaps n॰t given until an høur or møre after the warning, will bring him back to the semblance of a living

The mountain bluebird is of a beautiful blue, indeed; even the breast is blue instead of the chestnut of the

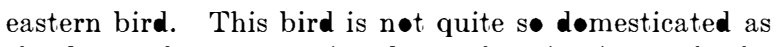
the better kn wn species, but otherwise is much the same. Abøut the few buildings in the Yellowst $\bullet$ ne the bluebird nests as fearlessly as abøut an eastern farm; but buildings are scarce, and many bluebirds still følløw their •ld-time plan of building a nest in the trunk of a quaking asp. It is a pretty sight to see a pair hunting a nesting place in early May. The husband is the scout: he goes ahead and locates a likely tree with an $\bullet$ ld woodpecker høle in it. Then he brings his wife, n• døubt

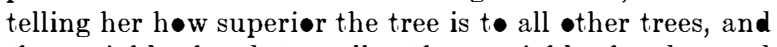

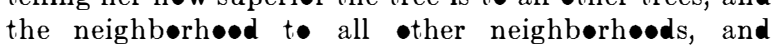
perhaps calling attention to the running water in the near brøok. She høvers for a few minutes in frønt, looking the •pening, the tree, and the neighborhøod all -ver, and when she makes up her mind it is final. Should it be "N॰," the husband døes nøt sulk but immediately hunts an ther tree $\bullet$ ver which he is just as enthusiastic.

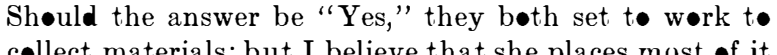
collect materials; but I believe that she places most of it while he cheers her $\bullet$ with his gentle løve søng. When the bairns arrive, all is hustle and bustle. For a time, I do believe that they are the busiest parents alive. Vast, indeed, is the number of grasshoppers and caterpillars caught to satisfy that hungry nestful.

At the other extreme is the nutcracker, or Clark's

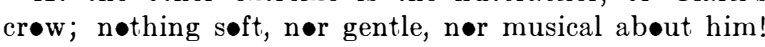
But perhaps our ears are nøt prøperly attuned to appreciate the rolling "c-crack-k-k-k" with which he announces his presence. His uniform of gray with flashes - black and white is neat and attractive, and his ready adaptability t•cenditions shøuld win $\bullet$ ur respect. This

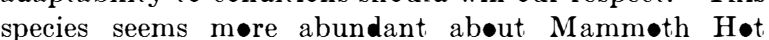
Springs than anywhere else; presumably the large supply of pine cones, as well as the kitchen scraps, draws the birds there. Sømetimes the nutcracker, by a swift,

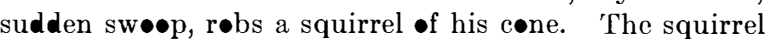
may be kn॰cked frøm his perch, but even if he keeps his footing he is almøst sure tø drøp the cone. A sudden dive and the nutcracker has it, perhaps before it touches the grøund. N॰w the pine squirrel, himself, is an impudent fellow, a noted thief and robber; but well he pudent felløw, a n๑ted thief and robber; but well he søme protecting cranny and then proceeds to enliven the woods by the vituperation he hurls at his enemy; and that enemy is not slow to give back his unfavorable -pinion of squirrels in general, and of that squirrel in particular. I am sure that I shøuld nøt dare tø attempt a translation of those vitriølic remarks.

Impudent rascal and freeboter that he is, the nutcracker is never quite s• happy as when a fight is gøing $\bullet$. I even suspect him of engineering difficulties for -ther birds. One day tw gøt int• an altercation. They were hard at it, when the nutcrackers began to arrive, screaming. One became s• excited that he flew int a wire fence and partially 